\title{
The Role of Islamic Banking in the Development of Economic Sectors in Indonesia
}

\section{Iwan Setiawan*}

Associate Professor, Department of Accounting, Politeknik Negeri Bandung, Indonesia

Received 10 October 2018; accepted 4 May 2019

\begin{abstract}
Islamic banks can play a role in improving the welfare of the community. Through the intermediary function, Islamic banks raise funds deposits and channel the financing for productive purposes. The purpose of this study is to examine the role of Islamic bank financing to increase economic productivity and job creation. This study used simultaneous panel estimation technique with Two Stage Least Square (TSLS) method, using secondary data from 2005-2016. The results of this study revealed that the financing of Islamic banks play a role in increasing economic activity and employment, the role of Islamic banks finance is larger than the role of conventional bank credit, although the contribution is not too large. The regression result per sector of economy indicated that financing of Islamic bank gives positive role to increase economic activities in each sector. On the other hand, the role of financing for job creation by economic sector showed different results. Most Islamic banking financing in the economic sector ( 7 sectors) provided a positive role for job creation. However, the financing in the agricultural and mining sectors played a negative role in job creation.
\end{abstract}

\section{KEYWORDS}

Islamic bank financing

Productivity

Employment

Economic structure

\section{INTRODUCTION}

In 2016 the Indonesian economy was marked by the low contribution of the agricultural sector to GDP formation (13.30\%) but contributed significantly to employment (31.74\%). In contrast, the industrial sector contributed substantially to the formation of GDP (22.18\%) but low in its ability to create employment (13.24\%). The contribution of the economic sector to GDP and employment is less supportive to the process of changing the structure of the economy in Indonesia. Whereas, according to Lankauskienė and Tvaronavičienè (2013), changes in structure through increased productivity performance of the economic sector is a key factor in the success of sustainable development.

Loan or financing provided by Islamic bank has the potential contribution to the changes in economic structure. Islamic bank financing has experienced rapid growth, exceeding the loan of conventional bank. In 2016, the growth of Islamic bank financing and conventional bank loans were $16.44 \%$ and $7.85 \%$ respectively. Therefore, Islamic banks should have a major impact on the national economy because of its contribution to employment, GDP and its flexibility and 
resilience in crisis (Kara, 2013a). Moreover, low inflation and accelerated economic growth are due to the role of Islamic bank under Indonesia's dual banking system (Ascarya, 2014).

The development of Islamic bank financing is expected to improve the economic structure. Financing in the agricultural sector is still being a main reason for increasing jobs. Financing of Islamic banks in the agricultural and industrial sectors continued to increase by the average growth of $19.27 \%$ and $26.04 \%$ per year (Figure 1). Despite the increase, the share of Islamic bank financing allocation for agriculture and industry sectors was still very small. Islamic bank financing portfolio for agriculture and industry sectors averaged 3.02\% and $4.12 \%$ per year, much lower than the portion of Islamic bank financing in the service sector which reached $29.76 \%$ per year.

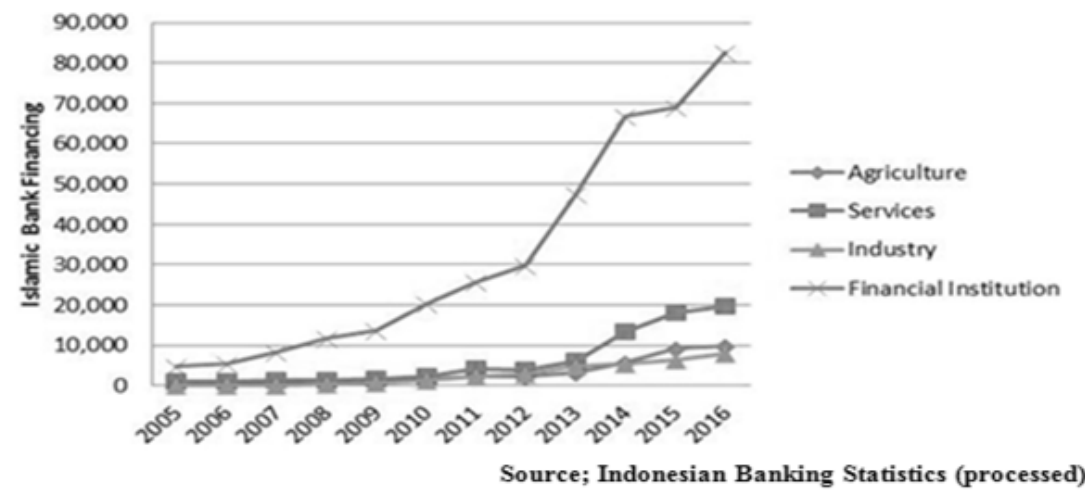

Figure 1. Islamic Banks financing for economic sectors in Indonesia 2005-2016 (in billion Rupiah)

Islamic bank financing is important for increasing productivity and employment sectors. According to (Gemmell, Llyod, \& Mathew, 2013), bank financing and increased productivity in the industrial sector will be followed by the increased capacity of the agricultural sector. The growth of the agricultural sector is the best way to increase rural employment (Suryadarma, et al, 2007). Bank financing in the economic sector should be run appropriately. Scholars (Paci, Sasin, \& Verbeek, 2004) reveal that productivity growth reduces unemployment although overproductivity growth can reduce non-formal employment and increase unemployment. It needs appropriate strategies to channel the financing to the economic sectors so the contribution will be in line with the economic growth and job creation.

The low allocation of financing to the agricultural and industrial sectors as well as the continued dualism of the Indonesian economy has caused the role of Islamic bank in encouraging the development process is less optimal. Based on this problem, the objectives of this research are: 1) to identify the financing of Islamic bank, the development of output and national employment in the economic sectors and 2) to examine the model of relationship between financing with output growth and employment in the economic sectors. 


\section{REVIEW OF LITERATURE}

Islamic banks are part of the banking system in Indonesia. The high growth of Islamic bank financing shows the huge potential of the banking industry to improve the economic condition. Credit and financing can boost economic growth (Ascarya, 2010). The occurrence of the monopoly competition market structure trends in the dual banking system (Mohamed, Ismail, \& Junaina, 2016) strengthens the influence of banking on inflation in the economy.

On a wider scale, credit and financing growth are expected to improve public welfare indicators through job creation, improve income distribution and decline numbers of poor people. According to Iqbal (2008), the implementation of Islamic bank should be able to achieve economic growth in full employment conditions. In addition, according to Abiad and Gopvanni (2011), it is almost impossible to improve the economy without credit growth. The decline in the role of credit in the aggregate and sectorial economy is due to disruptions in the financial sector intermediation function. The imperfections of the credit market affect decisions on the addition of labors and corporate expenses (Mishkin, 2008). Credit and financing of Islamic banks add the potential for the development of the economic sector through the increase of venture capital. Problems arise when credit and financing are only channeled to the capital-intensive business sector without regard to their impact on employment. The increase in capital affects the rising unemployment rate. According to Yusuf, Komarulzaman, Purnagunawan, and Resosudarmo (2013), the intensification of capital use and the acceleration of real wage growth can be a major cause of unemployment growth in Indonesia's manufacturing sector.

Credit and financing in the economic sector have different portions and sensitivities in responding to monetary policy. Alam and Waheed (2006) reveal that monetary policy has different sectorial effects. The industrial sector, wholesale and retail trade, finance and insurance sectors are more responsive to interest rate shocks. In contrast, agriculture, mining and quarrying, construction and home ownership are insensitive to changes in interest rates. Saibu and Nwosa (2011) show the results of different studies, which the industrial sector is not sensitive and the agricultural sector is more responsive to changes in interest rate policy. Setiawan (2013) points out that banking credit in all sectors of the economy, excluding mining and quarrying, has a positive effect on job creation. On the other hand, overall economic growth has had an unfavorable impact on job creation. Economic growth that occurs in all sectors of the economy will actually reduce the creation of employment. A review by Sukmana (2011) shows that Islamic banks play an important role in the process of monetary transmission in the Indonesian economy. There is a negative relationship between SBIS and Industrial Production Index (LIPI). Islamic monetary policy supports a tangible effect on economic activity.

Cambazoğlu and Karaal (2012) show that through credit, changes in money supply impact employment creation and output. Ozcelebi (2011) emphasize the importance of coordinating monetary and fiscal authorities to maintain price stability, encouraging banks to address unemployment issues. Camargo and Cortez (2011) and Cortez (2011) show that the impact of monetary policy on unemployment has low levels of elasticity. This condition is caused by high regulation but low enforcement of rules and large presence of informal sector in labor market. The study by Szirmai (2012) reveals that the development of the modern sector (industry) becomes the motor of development in various countries. Increased GNP will continue on a continuous basis until a new equilibrium is reached. An increase in GNP is economic sourced in the modern sector whose role is increasing, while the role of the traditional sector is declining. 
Studies by Furceri (2012) reveals that high unemployment, especially among youth, is due to the relatively low elasticity between job-output and the rigid labor market. Improvement in labor market conditions will be the key in reducing unemployment in the short and medium term. Labor spreads across different sectors of the economy with different amounts and growth rates. Banking can play an active role in creating jobs and reducing this unemployment rate.

Referring to the research problem and the theoretical study conducted, the research was conducted based on the following framework of thought (Figure 2).

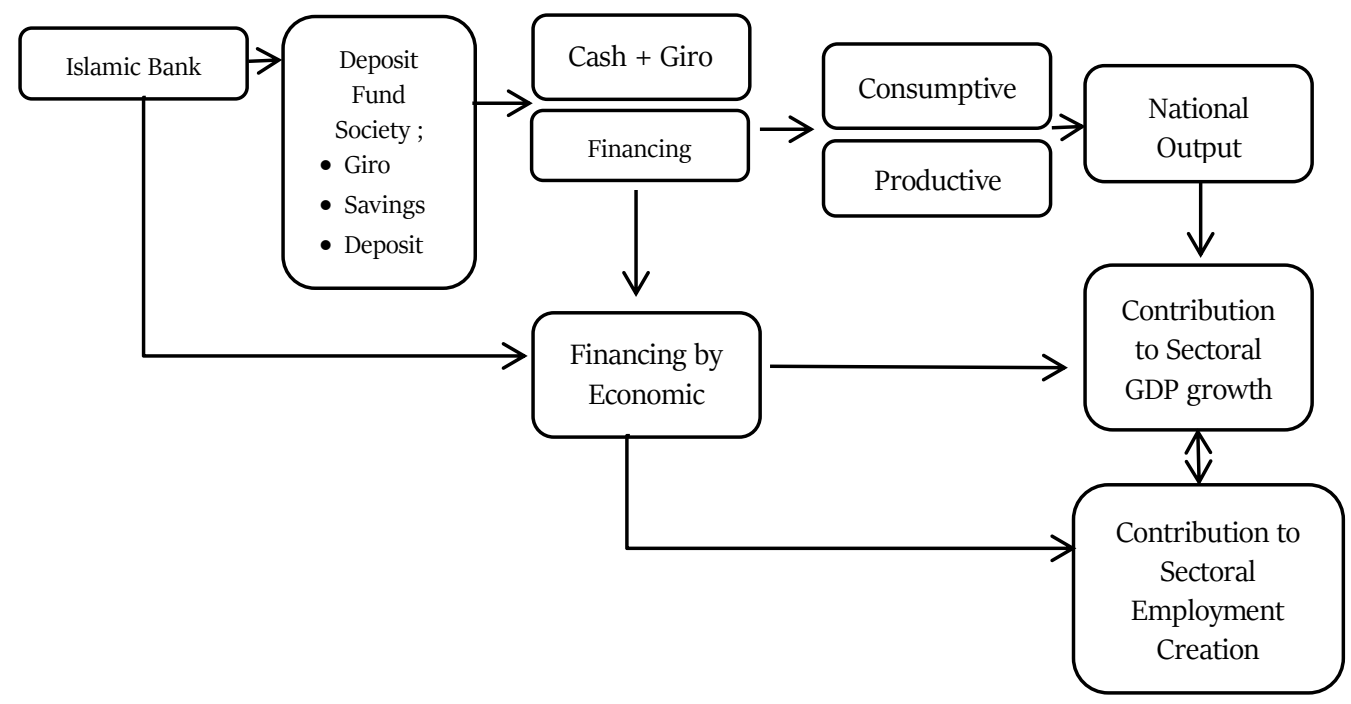

Figure 2. Research thinking framework

This research studies the role of Islamic banking in contributing to changes in economic structure. Islamic banking is predicted to play a potential role in economic growth and job creation. Islamic banking financing is expected to give a role in increasing output and employment in each sector of the economy.

\section{RESEARCH METHOD}

The object of this study were three important components, namely 1) the activities of Islamic banks, 2) the productivity of economic activities, and 3) labor market. The activities of Islamic banks were reviewed through financing for each sector of the economy (9 sectors), with the orientation of the use of financing for consumptive and productive purposes (working capital and investment), in accordance with the financing contract that is executed. The data used in this study was secondary data, consisting of the time series of the quarterly periods of 2005-2016 and cross section for nine (9) economic sectors receiving the allocation of financing from Islamic bank in Indonesia.

The research data included economic sector contribution data to GDP, labor, credit amount and financing in each economic sector, consumer price index, Islamic monetary policy instrument, and wage rate. The data were obtained through library research and computerization method (computerized search). The overall data were obtained from the publications and web 
sites of Bank Indonesia, the Financial Services Authority (OJK), the Central Bureau of Statistics (BPS), the Ministry of Agriculture, the Ministry of Industry and other departments concerned.

The method of analysis used in this research was descriptive qualitative analysis method and quantitative analysis method. This model of analysis is relevant for social studies that try to see, measure and test the relationships among variables. This model of analysis is also suitable for studies directed to test the hypothesis. The model of analysis in this study used simultaneous panel estimation technique using Two Stage Least Square method, TSLS (Gujarati, 2009).

The research model of the influence of Islamic bank financing on the establishment of national output and employment is presented through the following structural equations;

$$
\begin{aligned}
& \operatorname{Grw}_{i t}=\alpha_{0}+\alpha_{1} \text { Fin }_{i t}+\alpha_{2} \operatorname{Crd}_{i t}+\alpha_{3} \operatorname{Emp}_{i t}+\varepsilon_{1} \\
& \operatorname{Emp}_{i t}=\beta_{0}+\beta_{1} \text { Fin }_{i t}+\beta_{2} \operatorname{Crd}_{i t}+\beta_{3} G r w_{i t}+\varepsilon_{2} \\
& \text { Where: } \\
& \text { Grw }=\text { Economic sector contribution to GDP formation } \\
& \mathrm{Emp}=\text { Number of labor in each economic sector } \\
& \text { Fin } \quad=\text { Islamic bank financing by economic sector } \\
& \mathrm{Crd} \quad=\text { Conventional banking credit by economic sector }
\end{aligned}
$$

Based on the above two structural equations, it appears that the variables have interdependence with each other. The research variables are categorized as endogenous and exogenous (predetermined variable). This condition shows that this research model is qualified to be applied to simultaneous equations. The proposed hypothesis design to be tested against the main variables in this study were: (1) Islamic bank financing positively affects the growth of national output, and (2) Islamic banks financing positively effects the job creation in the economic sectors.

\section{RESULTS AND DISCUSSION}

\section{Financing, GDP, and Employment}

In the period of 2005-2016, Islamic bank financing grew an average of $28.8 \%$ per year. There was a difference in the allocation of Islamic bank financing among economic sectors. The business services sector experienced the most progressive growth and received the largest average allocation of $41.90 \%$ per annum. On the other hand, the electricity, gas and water sectors received the lowest average allocation of $2.7 \%$ per year. The high growth of Islamic bank financing shows the huge potential of the banking industry to improve the economic condition. According to Ascarya, 2010, financing can increase economic growth. Financing through the economic sectors can improve the productivity of economic performance so as to support changes in economic structure and sustainable development (Lankauskienė \& Tvaronavičienė, 2013).

In the period of 2005-2016, conventional bank credit grew an average of $19.3 \%$ per year. The highest growth of $24.57 \%$ occurred in 2012 and the lowest growth of $6.67 \%$ occurred in 2009 . There were differences in growth patterns and the amount of bank credit in the economic sectors. In 2016 the electricity, gas and water sectors experienced the largest growth rate (36.45\%), and the lowest growth occurred in the mining sector by $-8.62,44 \%$. In the period of 2005-2016, trade, restaurant and hotel sector received the largest allocation of $29.13 \%$ per annum on average, with the highest allocation occurred in 2015 of $30.36 \%$ and the lowest allocation in 2011 of $26.94 \%$. 
The mining sector received the lowest average allocation of $4.12 \%$ per annum with the highest allocation occurring in 2011 of $5.56 \%$ and the lowest allocation occurring in 2005 of $1.63 \%$.

In the period of 2005-2016, Indonesia's GDP grew an average of 5.65 per year. There were differences in growth patterns and economic sector contribution to GDP formation. In the period of 2005-2016, the highest growth occurred in transportation and communications sector which experienced an average growth rate of $11.76 \%$ per year. The lowest growth occurred in the mining and quarrying sector which experienced growth of only $1.49 \%$ per year. The economic sector that gave the highest contribution to the formation of GDP was the manufacturing processing sector. This sector contributed an average of $26.25 \%$ per year. Economic sector that contributed the smallest to the formation of GDP was the sector of electricity, gas and water supply. This sector contributed an average of $0.74 \%$ per year.

The condition of Islamic bank financing development, conventional bank credit, Gross Domestic Product value and employment per sector of the economy in Indonesia are presented in the Table 1.

Table 1. Summary of condition of research object

\begin{tabular}{|c|c|c|c|c|c|}
\hline \multirow{2}{*}{ No. } & \multirow{2}{*}{ Variable } & \multicolumn{2}{|c|}{ Growth at Sector } & \multicolumn{2}{|c|}{ Share Sector } \\
\hline & & Highest & Lowest & Highest & Lowest \\
\hline 1. & Financing & $\begin{array}{l}\text { Electricity, Gas \& } \\
\text { Water }\end{array}$ & $\begin{array}{l}\text { Transportation, } \\
\text { Warehousing \& } \\
\text { Communication }\end{array}$ & $\begin{array}{l}\text { Financial } \\
\text { Institution, Real } \\
\text { Estate, etc. }\end{array}$ & $\begin{array}{l}\text { Electricity, Gas } \\
\text { \& Water }\end{array}$ \\
\hline 2. & Credit & Social Services & Industry & $\begin{array}{l}\text { Trade, } \\
\text { Restaurant \& } \\
\text { Hotel }\end{array}$ & $\begin{array}{l}\text { Electricity, Gas } \\
\text { \& Water }\end{array}$ \\
\hline 3. & GDP & $\begin{array}{l}\text { Transportation, } \\
\text { Warehousing \& } \\
\text { Communication }\end{array}$ & $\begin{array}{l}\text { Mining and } \\
\text { Excavation }\end{array}$ & Industry & $\begin{array}{l}\text { Electricity, Gas } \\
\text { \& Water }\end{array}$ \\
\hline 4 & Employment & $\begin{array}{l}\text { Financial } \\
\text { Institution, Real } \\
\text { Estate, etc. }\end{array}$ & Agriculture & Agriculture & $\begin{array}{l}\text { Electricity, Gas } \\
\text { \& Water }\end{array}$ \\
\hline
\end{tabular}

In the period of 2005-2016, employment in Indonesia grew an average of 1.98 per year. There was a difference in growth patterns and the amount of labor in the economic sector. In the period 2005-2016, the highest employment growth occurred in the financial services sector which experienced an average growth of $10.68 \%$ per year. The lowest growth occurred in agriculture sector which experienced a growth of minus 5.8\% per year. Despite the negative growth, the agriculture, plantation, forestry, hunting and fisheries sectors still provided the highest contribution to job creation. These sectors contributed an average of $37.56 \%$ per year. Economic sectors that provided the smallest contribution to job creation were electricity, gas and water supply. This sector contributes an average of $0.23 \%$ per year.

Ahmad (2008) reveals that economic growth in developing countries including Indonesia cannot be separated from the role of bank credit. For countries of which the capital market has not been so developed, bank credit effectively affects the economy. The crisis in Indonesia according to Mendoza and Terrones (2008) is also related to the increase in credit, which is preceded by large capital inflows but not accompanied by reform of the financial system. 


\section{The Role of Islamic Bank Financing on the Growth of National output and employment}

In an economy that implements a dual banking system, credit and financing of Islamic banks play a role in economic growth. The studies by Rusyidiana (2009) and (Ascarya, 2010) reveal that productive financing positively affects real sector output which enables balanced growth between the monetary sector and the real sector. Through the role of intermediation, banks can play an active role in economic development. Financing activities of Islamic and conventional bank loans can support to increase economic activities and employment. The change in national output and employment created is strongly influenced by the role of banks in optimizing the role of intermediation, especially the allocation of funds to the productive sector of the economy.

The relationship between Islamic bank financing and national output development is presented in the National Output Development Model. The results of data processing and statistical tests are presented as follows:

\section{Model of National Output Development}

$$
\begin{aligned}
& G r w_{i t}=178821.8+0.628 \text { Fin }_{i t}+0.367 \mathrm{Crd}_{i t}+1.613 \mathrm{Emp}_{i t} \\
& \text { (21.824) (7.368) (16.633) (2.367) } \\
& \text { R-squared } \quad 0.976770 \quad \text { Mean dependent var } 269524.0 \\
& \text { F-statistic } \quad 366.9645 \quad \text { Durbin-Watson stat } \quad 0.192376
\end{aligned}
$$

The National Output Development Model reveals that GDP in the economic sector is significantly affected by financing and credit. Any increase in Islamic bank financing will contribute to the increase of GDP in Indonesia. The role of Islamic bank financing in encouraging economic growth is still relatively small. This condition is in accordance with the study of Kasim (2016) which reveal that credit and financing play a role in improving economic growth. The same condition occurs in conventional bank credit. Any conventional bank credit increase will contribute to the increase in GDP. The role of Islamic bank financing is greater than bank credit to the development of national output. A study by Hasan and Dridi (2010) reveals that Islamic bank financing gives better contribution to financial and economic stability than the conventional banks.

Available employment opportunities and the workforce involved also provide a positive and significant role in the development of national output. Any increase in manpower that can be involved contributes greatly to the increase in economic activity. The results of fund processing and statistical tests show that any increase in employment created will contribute to the increase in GDP. Its role is quite large, so efforts to create jobs by the government and various parties will contribute to the increase of economic activities.

\section{Model of Employment Creation}

The relationship between Islamic banks financing and employment development is presented in the Employment Creation Model. The results of data processing and statistical tests are presented as follows: 


$$
\begin{aligned}
& E m p_{i t}=9963.475+0.012 F_{i n}+0.006 C r d_{i t}+0.003 G r w_{i t} \\
& \begin{array}{llll}
(32.735) \quad(2.566) \quad(5.539) \quad(2.518)
\end{array} \\
& \text { R-squared } \quad 0.990748 \quad \text { Mean dependent var } \quad 11902.95 \\
& \text { F-statistic } \quad 934.5544 \quad \text { Durbin-Watson stat } \quad 0.248104
\end{aligned}
$$

The role of banks in financing activities (Islamic banks) and credits (conventional banks) is expected to contribute in tandem to the creation of employment. Iqbal (2008) reveals that the implementation of Islamic bank activities should be able to achieve economic growth in full employment conditions. The results of data processing and statistical tests show that employment in the economic sector is significantly influenced by the financing of Islamic banks, conventional bank credit and accelerated economic growth that occurred. The results of this study are relevant to the study by (Kara, 2013), which reveals the magnitude of the potential of Islamic bank on employment and increased Gross Domestic Product (GDP).

Islamic bank financing provides a positive role for job creation. Any increase in Islamic bank financing will contribute to the increase of personnel. The same condition is shown by the role of credit to job creation. Any conventional bank credit increase will contribute to the absorbed workforce. Job creation is also influenced by the economic activity that occurs. Acceleration of economic growth gives a positive and significant role in the increase of employment although its role is not too big. Any increase in GDP will contribute to additional labor. Ideally, Islamic banks can encourage financial intermediation on the basis of profit-loss sharing so as to assist the management of Islamic economics in minimizing unproductive elements and encouraging the real sector and job creation (Chapra, 2007).

\section{The Role of Islamic Bank Financing}

Overall financing of Islamic banks contributes positively and significantly to economic growth and job creation. When assessed by economic sectors that get Islamic bank financing, the role of financing to economic growth and job creation in each sector shows different results. Studies from Nature and Waheed (2006) and (Saibu \& Nwosa, 2011) and Nwosa I (2011) reveal that each sector of the economy has a different sensitivity in responding to the policy of the monetary authorities. The manufacturing sector is insensitive while the agricultural sector is responsive to changes in monetary policy interest rates.

The role of Islamic bank financing on the establishment of GDP and employment by economic sectors is presented in Table 2. Based on the results of data and statistical tests, Islamic bank financing provides a positive and significant role to economic growth in each sector of the economy. The results of this study are in accordance with the study of Hakim and MA (2016) which reveals that financing can increase economic growth. Financing of Islamic banks in the mining and quarrying sectors provides the greatest role in increasing GDP in Indonesia. Any increase in financing in this sector leads to an increase in GDP. This condition shows that the potential effect of multiplier process of financing mining sector and excavation on economic development in Indonesia is bigger than the other sectors. Islamic bank financing in social and individual services sector provides the second largest role for economic growth. The role of Islamic banking financing in the industrial sector gives the smallest contribution to the development of sectorial GDP value in Indonesia.

Based on the results of data and statistical tests, overall Islamic bank financing contributes positively and significantly to job creation. Based on the economic sector that obtains financing, 
the role of Islamic banks in job creation in each sector shows different results. There are seven sectors of the economy that respond positively and two economic sectors that respond negatively to every Islamic bank financing on job creation. The allocation of financing in these two sectors has the potential to create unemployment.

Furceri (2012) reveals that high unemployment, especially among youth, is due to the relatively low elasticity between job-output and the rigid labor market. The improvement of the labor market will be the key in reducing unemployment in the short and medium term. Labor spreads across different sectors of the economy with different numbers and growth rates. Ozcelebi (2011) reveals that the increase in bank credit affects real economic growth and an increase in interest rates leads to a decrease in the labor force participation rate.

Table 2. Relationship of Islamic bank financing with Economic Growth and Job Creation

\begin{tabular}{|c|c|c|c|c|c|c|c|c|c|}
\hline \multirow{2}{*}{ No. } & \multirow{2}{*}{ Sector } & \multicolumn{4}{|c|}{ Economic Growth Model } & \multicolumn{4}{|c|}{ Employment Model } \\
\hline & & Constants & coefficient & t-stat & $\mathrm{R}^{2}$ & Constants & coefficient & t-stat & $\mathrm{R}^{2}$ \\
\hline 1. & $\begin{array}{l}\text { Agriculture, } \\
\text { Plantation, } \\
\text { Forestry, Hunting } \\
\text { and Fisheries }\end{array}$ & 276,763 & 10.95 & 6.06 & 0.79 & 41,176 & -0.38 & $-5 \cdot 31$ & 0.74 \\
\hline 2. & $\begin{array}{l}\text { Trade, Restaurants } \\
\text { and } \\
\text { Accommodation } \\
\text { Services }\end{array}$ & 175,315 & $3 \cdot 32$ & 2.78 & 0.44 & 1,091 & 0.07 & 2.59 & 0.40 \\
\hline 3. & $\begin{array}{l}\text { Social, Social, and } \\
\text { Individual Services }\end{array}$ & 547,736 & 14.03 & 7.09 & 0.83 & 12,918 & 0.16 & 3.43 & 0.54 \\
\hline 4. & Industry & 14,297 & 1.38 & 7.61 & 0.85 & 199 & 0.02 & 8.38 & 0.88 \\
\hline 5. & Construction & 105,169 & 8.45 & 12.74 & 0.94 & 4,510 & 0.27 & 9.64 & 0.90 \\
\hline 6. & $\begin{array}{l}\text { Transportation, } \\
\text { Warehousing and } \\
\text { Communication }\end{array}$ & 331,896 & $7 \cdot 45$ & 7.18 & 0.84 & 19,913 & 0.21 & 6.73 & 0.82 \\
\hline 7. & $\begin{array}{l}\text { Mining and } \\
\text { excavation }\end{array}$ & 49,861 & 51.16 & 11.18 & 0.93 & 6,038 & -0.15 & -2.13 & 0.31 \\
\hline 8. & $\begin{array}{l}\text { Financial } \\
\text { Institution, Real } \\
\text { Estate, Rental } \\
\text { Business, and } \\
\text { Company Service }\end{array}$ & 171,815 & 2.04 & 14.17 & 0.95 & 1,260 & 0.03 & 9.04 & 0.89 \\
\hline 9. & $\begin{array}{l}\text { Electricity, Gas and } \\
\text { Drinking Water }\end{array}$ & 171,035 & 9.80 & 8.12 & 0.87 & 11,698 & 0.65 & 6.56 & 0.81 \\
\hline
\end{tabular}

The results of this study indicate that financing of Islamic banks in the sector of electricity, gas, and drinking water provides the greatest role to increase employment in Indonesia. Each 1 billion Rupiah increase in financing in this sector results in an increase in employment of 645 people. This condition shows that the effect of multiplier process of financing of electricity, gas and drinking water sector towards job creation in Indonesia is bigger than the other sectors. Financing in the construction sector gives the second largest role to job creation. Each 1 billion Rupiah increase in financing in this sector results in an increase in employment of some 267 people

According to scholars (Suryadarma, Suryahadi, \& Sumarto, 2007), the growth of the agricultural sector is the best way to increase employment in rural areas. The results of this study reveal that the financing of Islamic banks in the sector of mining and agriculture gives a negative 
role to the creation of employment. Any increase in Islamic bank financing in these two sectors has resulted in a decrease in employment, contributing to an increase in the unemployment rate. This condition arises when credit and financing are only channeled to a capital-intensive business sector without regarding to its impact on employment. The increase in capital affects the rising unemployment rate (Yusuf et al., 2013). Financing of Islamic banks in the agricultural sector and the mining sector has not been expected to play a role in the development of the economic sector, especially in the creation of employment

\section{CONCLUSION}

The description of the financing conditions of Islamic banks, GDP and employment are as follows: 1) Islamic banking financing in Indonesia has grown rapidly beyond the level of conventional bank credit growth, thus potentially contributing more to economic progress. Financing of Islamic banks is distributed in different sectors of the economy. Sectors of financial institutions, real estate, business leasing and services companies on the average obtain the largest bank financing allocation. The mining and quarrying sector obtains the smallest bank financing allocation. 2) The development of national output in Indonesia is relatively stable and high with the average growth rate of Gross Domestic Product (GDP) of 5.65\% per year. Economic sectors experiencing the highest growth rates are transport and communications sector while mining and quarrying sector experience the average of the smallest economic growth rate. The economic sector that gives the largest contribution to the increase of GDP is the manufacturing processing sector. Economic sectors for electricity, gas and water supply contribute the smallest to the increase of GDP. 3) Employment in Indonesia is experiencing relatively slow growth, with an average growth rate of $1.98 \%$ per year. Employment in the financial services sector experiences the highest average growth and the agricultural sector grew at the slowest pace. The agriculture sector still contributes the most and the sector of electricity, gas and water contributes the smallest in job creation.

Overall, Islamic bank financing provides a positive role for output and employment growth, albeit with a not-so-substantial role. 1) Financing of Islamic banks provides a positive role for economic growth in all sectors of the economy. Financing in the mining sector provides the greatest role and financing in the industrial sector gives the smallest role to the development of output of each sector. 2) Financing in the economic sector provides a different role to job creation. Financing in the seven sectors of the economy provides a positive role for employment creation. Financing in the agricultural sector and the mining sector provides a negative role for job creation. Financing of Islamic banks in these two sectors has not been able to provide an optimal role for the development of the economic sector, especially the role in job creation.

Economic development requires substantial funds. Islamic banking is one of the institutions that is expected to contribute amid the problem of limited development funds. Through financing, Islamic banks can encourage output growth and field job creation in the economic sectors. To encourage the role of financing so as to give the optimal role to the process of change of economic structure, then here are some suggestions: 1) Islamic Banks need to encourage and increase the amount of financing in the economic sector proven to have a major impact on the increase of national output and employment. 2) It is necessary to increase the third party funding source to increase the financing potential of Islamic banks, especially in the economic sector which has a big influence on the growth of output and employment but still receives the allocation of financing with a very limited portion. 3) It needs efforts to improve the performance of Islamic banks to improve competitiveness and public confidence. 


\section{REFERENCES}

Abiad, A., Giovanni, D., \& Li, B. (2011). Creditless Recoveries. IMF Working Paper, Research Department. pp. 1-30. Retrieved from: https://www.imf.org/en/Publications/WP/Issues/2016/12/31/Creditless-Recoveries-24707

Alam, T., \& Waheed, M. (2006). The Monetary Transmission Mechanism in Pakistan: A Sectoral Analysis. Institute of Development Economics. MPRA Paper No. 2719, Retrieved from: http://mpra.ub.uni-muenchen.de/2719/.

Ascarya. (2010). Peran Perbankan Islamic dalam Transmisi Kebijakan Moneter Ganda. Istishodia, Jurnal Ekonomi Islam Republika. Agustus 26, pp.1-5.

Ascarya. (2014). Monetary Policy Transmission Mechanism Under Dual Financial System In Indonesia; Interest-Profit Channel. International Journal of Economics, Management And Accounting, 22(1), 1-32.

Camargo, A. I., \& Cortez, W. W. (2011). How Relevant is Monetary Policy to Explain Mexican Unemployment Fluctuations. MPRA Paper No. 30027. Retrieved from: https://mpra.ub.unimuenchen.de/30027/1/MPRA_paper_30027.pdf

Cambazoğlu, B., \& Karaalp, s. (2012). The Effect Of Monetary Policy Shock On Employment and Output; The Case Of Turkey. International Journal Of Emerging Sciences (IJES), 2(1), 23-29.

Furceri, D. (2012). Unemployment and Labor Market Developments in Algeria. IMF WP/12/99, Middle East and Central Asia Department. Retrieved from: https://www.imf.org/en/Publications/WP/Issues/2016/12/31/Unemployment-and-LaborMarket-Issues-in-Algeria-25861

Gemmell, N., Llyod, T., \& Mathew, M. (2013). Dynamic Sectoral Linkages and Structural Change in a Developing Economy Centre for Research in Economic Development and International Trade: University of Nottingham.

Gujarati, D. N. (2009). Basic Econometrics (5th Ed.). New York: McGraw-Hill Companies.

Hakim, B. \& Md Akther, U. (2016). Does Islamic Bank Financing Lead to Economic Growth: An Empirical Analysis for Malaysia. MPRA No 69075. Retrieved from: https://ideas.repec.org/p/pra/mprapa/69075.html

Dridi, J., \& Hasan, M. (2010). The Effects of the Global Crisis on Islamic and Conventional Banks: A Comparative Study IMF Working Paper. International Monetary Fund WP/10/201. Retrieved from: https://www.imf.org/en/Publications/WP/Issues/2016/12/31/The-Effectsof-the-Global-Crisison-Islamic-and-Conventional-Banks-A-Comparative-Study-24183

Iqbal, Z. (2008). The Impact Of Consolidation On Islamic Financial Services Industry. Islamic Economic Studies, 15 No. 2, 79-101.

Kara, M. (2013a). Konstribusi Pembiayaan Perbankan Islamic Terhadap Pengembangan Usaha Mikro Kecil Dan Menengah (UMKM) Di Kota Makassar. Jurnal Ilmu Syariah dan Hukum, $47(1) .269-301$

Lankauskienė, T., \& Tvaronavičienė, M. (2013). Economic Sector Performance and Growth: Contemporary Approaches in The Context of Sustainable Development. Journal of Intellectual Economics, 7 No 3(17), 355-374.

Mishkin, F. S. (2008). The Economics of Money, Banking and Financial Market. Jakarta: Penerbit Salemba Empat.

Miyamoto, H. (2012). Growth and non-Regular Employment. Journal of Macroeconomics, 16(2), 523-554. doi: 10.1515/bejm-2015-0057

Mohamed, N., Ismail, A. G., \& Junaina, M. (2016). Concentration and Competition in Dual Banking Industry: A Structural Approach. Jurnal Ekonomi Malaysia, 5o(2), 49-70. 
Ozcelebi, O. (2011). Do Monetary Policy Stance and Participation Banking Influence The Real Economic Activity, Empirical Evidence From Turkey. International Research Journal of Finance and Economics (77), 153-166.

Paci, P., Sasin, M. J., \& Verbeek, J. (2004). Economic Growth, Income Distribution and Poverty in Poland during Transition Policy, Research working paper-series. pp. 1-18. World Bank Group: Development Research Group (DECRG). Retrieved from: http://documents.worldbank.org/curated/en/442341468776391182/Economic-growthincome-distribution-and-poverty-in-Poland-during-transition

Saibu, M. O., \& Nwosa, I. (2011). Monetary Policy on Sectoral Output Growth in Nigeria (19862008). Journal of Economics and Behavioral Studies, 2(6), 245-254.

Setiawan, I. (2013). Analisis Pengaruh Kredit Perbankan dan Kontribusi Sektoral Terhadap Penciptaan Lapangan Kerja; Analisis Sektoral Proses Pembangunan di Indonesia. pp. 37-43. Paper presented at the Industrial Research Workshop and National Seminar (IRWNS), Bandung.

Sukmana, R. (2011). Economic sectors sensitivity to Islamic and conventional Monetary Instrument: Case study in Indonesia. pp. 1-16. Paper presented at the 8th International Conference on Islamic Economics and Finance, Doha-Qatar.

Suryadarma, D., Suryahadi, A., \& Sumarto, S. (2007). Reducing Unemployment in Indonesia: Results from a Growth-Employment Elasticity Model. Working Paper. Smeru Research Institute. pp. 1-27. Retrieved from: http://www.smeru.or.id/en/content/reducingunemployment-indonesia-results-growth-employment-elasticity-model

Szirmai, A. (2012). Industrialisation As An Engine Of Growth In Developing Countries, 19502005. Journal Structural Change and Economic Dynamics 23(4), 406- 420. doi: 10.1016/j.strueco.2011.01.005

Yusuf, A., Komarulzaman, A., Purnagunawan, M., \& Resosudarmo, B. (2013). Growth, Poverty, And Labor Market Rigidity In Indonesia, A General Equilibrium Investigation Working Paper In Economics and Development Studies (WoPEDS) 201304, Center For Economics And Development Studies. Bandung: Department of Economics, Padjadjaran University. 